\title{
Draft Minutes of August 2017, APSA All Member Business Meeting
}

\author{
Thursday, August 31, 2017 \\ San Francisco, CA - Hilton Union \\ Square
}

\section{CALL TO ORDER}

President David Lake calls the meeting to order and, noting the lack of a quorum, explains that any votes taken at the meeting will be advisory and will not be binding.

\section{REPORTS}

D. Lake welcomes attendees and gives the President's report, focusing on the implementation of governance reform and the adoption of the new anti-harassment policy and ombuds program at the annual meeting. Treasurer Taeku Lee presents the Treasurer's Report, which indicates that the association is continuing in sound financial shape with \$36.27 million in investments, including $\$ 16.24$ in the Trust and Development Portfolio, and $\$ 16.29$ in the CFP Trust Portfolio as of July 31,2017 . T. Lee adds that as of June 30, 2017 APSA's is projecting revenue of $\$ 7.6$ million from operations and operating expenses of $\$ 6.9$ million, for a year-end net profit of $\$ 689$ thousand. J. Carens inquires as to whether APSA uses ethical investment principles or is looking into that moving forward. T. Lee notes that this is under discussion, but the council is in the process of evaluating APSA's investments more generally. C. Brenner notes that she welcomes steps toward ethical investment and encourages APSA to keep the membership informed on these efforts.

\section{ELECTION UPDATE}

S. Smith reports on the APSA Council Election on behalf of the Rules and Elections Committee. The APSA elections were held between July 19 and August 18, 2017. The ballot consisted of the Nominating Committee's slate of council and officer nominees, and no additional nominees by petition were submitted. This was the first election under the new APSA bylaws, which were approved in a vote by the full membership in October 2016. Under these bylaws, members could vote for, against, or abstain for each position. A quorum of $10 \%$ of the APSA membership, or 1207 completed ballots, was required. In total, 3107 ballots were cast, for turnout of $25.8 \%$. All nominees were resoundingly elected. The Rules and Elections Committee examined the vote tally and certified the election results.

\section{NEW BUSINESS}

D. Lake opens the floor to new business. J. Dean presents a statement expressing concern about the participation of Professor John Yoo on a panel at the annual meeting. The statement notes that the APSA Ethics Guide grievance procedures provide for the APSA Committee on Professional Ethics, Rights and Freedoms to hear individual grievances about any ethical problem or personal abuse experienced or caused by political scientists acting in their professional capacity. The committee will also become involved in cases involving the human rights of scholars in other countries, using the standards articulated in the International Declaration of Human Rights. The statement asks that the ethics guide be revised to allow for individual grievances to be filed against scholars whose work in a professional capacity has led directly to human rights abuses. C. Brenner supports the spirit of the statement but objects to the focus on a particular scholar and moves to strike any references to specific scholars when referring the ethics guide for revision. J. Dean accepts this change as a friendly amendment. J. Stevens expresses support for the statements but emphasizes the need for clear implementation procedures for handling such ethics complaints.
P. Passavant also expresses support for the statement, drawing attention to the changes that the American Psychological Association has made to its ethics code as a result of deliberations regarding the participation of psychologists in torture programs.

J. Stoner expresses concern about censoring debate, noting that definitions of human rights vary and alternative viewpoints should be heard and debated. M. Howell agrees on the importance of this type of ethical question, but expresses concern about opening decisions regarding specialized ethical questions to members generally. Some groups and sections are already having the relevant debates, and these debates should continue. J. Stevens and C. Brenner note that the statement simply calls on the Ethics Committee to look into the issue and consider revisions to the ethics guide. J. Carens expresses agreement, noting that there may be disagreement about the committee's findings but, given the concerns raised, the committee should at least deliberate on the issue.

S. Smith and D. Lake remind attendees that without a quorum any vote would not be binding, but note that the Ethics Committee does have the scope to take up the issue and the council is generally receptive to member concerns. C. Brenner requests a straw vote to gain a sense of the room, recognizing that the vote would not be binding. The vote is held on asking the Ethics Committee to consider changes to the ethics code to allow individual grievances to be filed based on human rights abuses. There are 31 votes in favor, 2 votes against, and 2 abstentions.

\section{ADJOURNMENT}

D. Lake passes the gavel to incoming APSA President Kathleen Thelen. K. Thelen thanks D. Lake for his work during his term, including his efforts on governance reform. D. Lake adjourns the meeting. 